Apocalypse of the Alien God 
DIVINATIONS: REREADING LATE ANCIENT RELIGION SERIES EDITORS

Daniel Boyarin

Virginia Burrus

Derek Krueger

A complete list of books in the series is available from the publisher. 


\section{Apocalypse of the Alien God}

PLATONISM AND THE EXILE

OF SETHIAN GNOSTICISM

Dylan M. Burns

\section{$\overline{\text { PENN }}$}

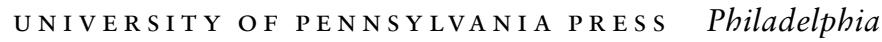




\section{MLL L}

THIS BOOK IS MADE POSSIBLE BY A COLLABORATIVE GRANT

FROM THE ANDREW W. MELLON FOUNDATION.

(C) 2014 University of Pennsylvania Press

All rights reserved. Except for brief quotations used for purposes of review or scholarly citation, none of this book may be reproduced in any form by any means without written permission from the publisher.

Published by

University of Pennsylvania Press

Philadelphia, Pennsylvania I9I04-4II 2

www.upenn.edu/pennpress

Printed in the United States of America on acid-free paper

IO9 $8765432 \mathrm{I}$

Library of Congress Cataloging-in-Publication Data

Burns, Dylan M.

Apocalypse of the alien god : Platonism and the exile of Sethian gnosticism / Dylan M. Burns. - Ist ed. religion)

p. cm. - (Divinations : rereading late ancient

Includes bibliographical references and index.

ISBN 978-0-8I 22-4579-o (hardcover : alk. paper)

I. Apocalyptic literature-History and criticism.

2. Gnostic literature-History and criticism.

3. Gnosticism. 4. Neoplatonism. I. Title.

BL5OI.B87 2014

$299^{\prime} .932-\mathrm{dc} 23$ 
Im Abstande erst erzeugt sich ja mein Leben.

—Gerschom Scholem, Tägebücher 2:245 
This page intentionally left blank 